\title{
TELL ES-SULTAN (JERICHO): RADIOCARBON RESULTS OF SHORT-LIVED CEREAL AND MULTIYEAR CHARCOAL SAMPLES FROM THE END OF THE MIDDLE BRONZE AGE
}

\author{
HENDRIK J. BRUINS \\ Jacob Blaustein Institute for Desert Research, Ben-Gurion University of the Negev \\ Sede Boker Campus 84990 Israel \\ and \\ JOHANNES VAN DER PLICHT \\ Centre for Isotope Research, University of Groningen, Nijenborgh 4, NL-9747 AG Groningen \\ The Netherlands
}

\begin{abstract}
Samples from Tell es-Sultan, Jericho, were selected for high-precision ${ }^{14} \mathrm{C}$ dating as a contribution toward the establishment of an independent radiocarbon chronology of Near Eastern archaeology. The material derives from archaeological excavations conducted by K. M. Kenyon in the 1950 s. We present here the results of 18 samples, associated stratigraphically with the end of the Middle Bronze Age (MBA) at Tell es-Sultan. Six short-lived samples consist of charred cereal grains and 12 multiyear samples are composed of charcoal. The weighted average ${ }^{14} \mathrm{C}$ date of the short-lived grains is $3306 \pm 7 \mathrm{BP}$. The multiyear charcoal yielded, as expected, a somewhat older average: $3370 \pm 6 \mathrm{BP}$. Both dates are more precise than the standard deviation $(\sigma)$ of the calibration curves and the absolute standard of oxalic acid. Calibration of the above Jericho dates is a bit premature, because several groups are currently testing the accuracy of both the 1986 and 1993 calibration curves. Nevertheless, preliminary calibration results are presented for comparison, based on 4 different calibration curves and 3 different computer programs. Wiggles in the calibration curves translate the precise BP dates into rather wide ranges in historical years. The final destruction of MBA Jericho occurred during the late 17th or the 16th century BC. More definite statements about the calibrated ages cannot be made until the accuracy of available calibration curves has been tested. Development of calibration curves for the Eastern Mediterranean region would be important.
\end{abstract}

\section{INTRODUCTION}

Charles Warren (1883) carried out exploratory excavations at Tell es-Sultan, Jericho, in 1867 and 1868. The first detailed archaeological excavations were conducted during $1907-1909$ and 1911 by Sellin and Watzinger (1913) in an Austrian-German expedition. Their archaeological age assignments were later revised by Watzinger (1926), who concluded that Middle Bronze Age (MBA) Jericho was destroyed by $1600 \mathrm{BC}$ at the latest. Garstang conducted excavations from 1930-1936. He dated the destruction of City IV to the Late Bronze Age and suggested an association with the biblical conquest (Garstang and Garstang 1948). However, Kenyon (1957), who excavated at Jericho from 1952-1958, assigned City IV to the MBA, which ended, in her assessment, ca. $1580 \mathrm{BC}$. She considered the new radiocarbon dating method too crude to be useful in Near Eastern studies after ca. $3000 \mathrm{BC}$, in comparison with archaeological age assessments (Kenyon 1960).

Thus, not many samples from Bronze Age Jericho were ${ }^{14} \mathrm{C}$ dated. By $1979,55{ }^{14} \mathrm{C}$ dates were obtained, but not a single MBA sample of the tell was included, although 7 MBA dates were acquired from the Tombs (Burleigh 1981). Another $19{ }^{14} \mathrm{C}$ dates were measured in 1981, but only 1 (BM-1790) relates to the MBA (Burleigh 1983). Unfortunately, these 19 dates are among those measured in the British Museum laboratory during a period for which a systematic uncertainty has been identified, which affects their reliability (Tite et al. 1987; Bowman, Ambers and Leese 1990).

The end of the MBA in the southern Levant is characterized by a large number of destroyed and abandoned archaeological sites (Weinstein 1981, 1991). Dever (1992) has reviewed various interpreta- 
tions of these archaeological data. Several scholars, including Kenyon, attribute the widespread destruction to the Egyptian army at the beginning of Dynasty XVIII. Bruins and Mook (1989) expressed the need for an independent ${ }^{14} \mathrm{C}$ chronology of Near Eastern Archaeology based on a series of new, high-precision ${ }^{14} \mathrm{C}$ dates, including historical and environmental data, to consider possible relations and interactions (Bruins 1994). We present here $18 \mathrm{new}{ }^{14} \mathrm{C}$ dates of Tell es-Sultan, based on 16 samples stratigraphically related to the end of the MBA. The material was excavated and labeled during the excavations by Kenyon in the 1950s. Six short-lived samples are composed of charred cereal grains and 10 samples consist of multiyear charcoal. One charcoal sample was split into three fractions, which were dated separately.

\section{METHODS}

The reported samples were analyzed at the conventional ${ }^{14} \mathrm{C}$ laboratory of the Centre for Isotope Research, Groningen, The Netherlands, in 1991 and 1992. All samples were treated by the acid/ alkali/acid (AAA) method, combusted to $\mathrm{CO}_{2}$ and purified (Mook and Waterbolk 1985). The samples were counted for 3-4 days to obtain the best possible precision; in most cases, enough material was available to use the large (25-liter) counter. We also report the $\delta^{13} \mathrm{C}$ values, used for fractionation correction.

\section{RESULTS}

\section{Multiyear Charcoal}

Tamarisk is the predominant wood type of charcoal found on the tell; it is also the most common present-day shrub or small tree in the area (Western 1971; Hopf 1983). The $12{ }^{14} \mathrm{C}$ dates of 10 charcoal samples from the end of the MBA gave surprisingly uniform dates (Table 1, Fig. 1). These results confirm ${ }^{14} \mathrm{C}$ laboratory precision at Groningen and archaeological accuracy with regard to stratigraphic relations. The one exception $(\mathrm{GrN}-18538)$ consists of the coarse fraction $(>0.425 \mathrm{~mm})$

TABLE 1. Sample Data and Results

\begin{tabular}{lcccl} 
Lab no. & $\begin{array}{c}{ }^{14} \mathrm{C} \text { date } \\
(\mathrm{yr} \mathrm{BP})\end{array}$ & $\begin{array}{c}\delta^{13} \mathrm{C} \\
(\% o)\end{array}$ & $\begin{array}{c}\text { Run } \\
\text { date }\end{array}$ & Material \\
\hline GrN-18539 & $3312 \pm 14$ & -23.09 & 1991 & Grains, Hordeum vulgare \\
GrN-18542 & $3288 \pm 20$ & -23.54 & 1991 & Grains, Triticum sp. \\
GrN-18543 & $3331 \pm 18$ & -23.31 & 1991 & Grains, Triticum sp. \\
GrN-18544 & $3312 \pm 15$ & -23.28 & 1991 & Grains, cereal, fragmented \\
GrN-19063 & $3240 \pm 18$ & -23.72 & 1992 & Grains, Hordeum vulgare \\
GrN-19064 & $3375 \pm 25$ & -21.86 & 1992 & Grains, cereal, fragmented \\
GrN-18363 & $3365 \pm 25$ & -26.28 & 1991 & Charcoal \\
GrN-18365 & $3360 \pm 25$ & -24.36 & 1991 & Charred wood \\
GrN-18367 & $3350 \pm 20$ & -25.70 & 1991 & Charred wood \\
GrN-18368 & $3393 \pm 17$ & -26.02 & 1991 & Charcoal \\
GrN-18370 & $3380 \pm 25$ & -25.32 & 1991 & Charcoal \\
GrN-18536 & $3342 \pm 17$ & -24.61 & 1991 & Charred wood \\
GrN-18537 & $3384 \pm 15$ & -25.98 & 1991 & Charcoal \\
GrN-19068 & $3350 \pm 16$ & -25.72 & 1992 & Charcoal \\
GrN-19223 & $3388 \pm 16$ & -25.62 & 1992 & Charcoal \\
GrN-18538 & $3614 \pm 20$ & -24.53 & 1991 & Charcoal >0.425 mm \\
GrN-18721 & $3385 \pm 20$ & -24.98 & 1991 & Charcoal <0.180 mm \\
GrN-18722 & $3368 \pm 17$ & -24.92 & 1991 & Charcoal 0.180-0.425 mm \\
\hline
\end{tabular}




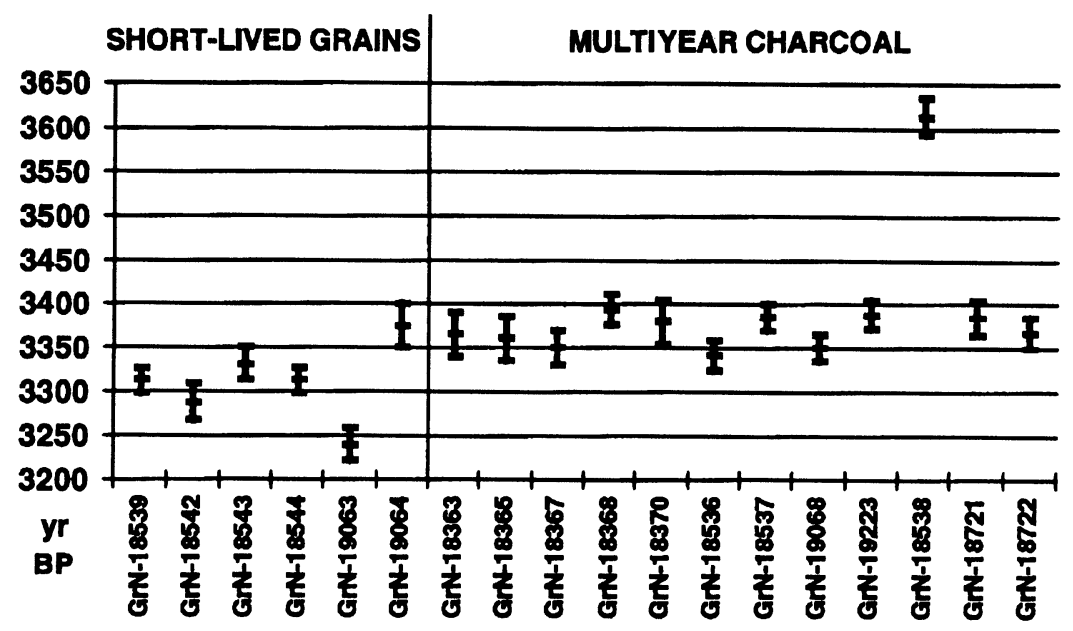

Fig. 1. End of Middle Bronze Age Jericho: ${ }^{14} \mathrm{C}$ dates in years BP

of a large charcoal sample, which was split in three fractions, dated separately (Fig. 2). The other two fractions $(<0.180 \mathrm{~mm}$ and $0.180-0.425 \mathrm{~mm})$ yielded dates $(3385 \pm 20 ; \mathrm{GrN}-18721$ and $3368 \pm$ 17 ; GrN-18722) similar to the nine other samples.

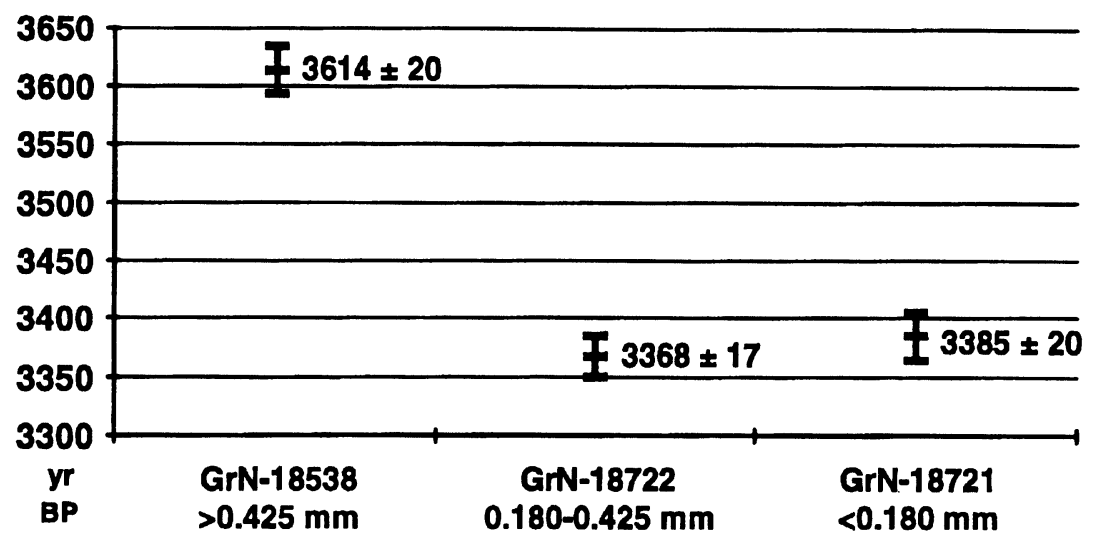

Fig. $2 .{ }^{14} \mathrm{C}$ dates BP of charcoal sample from Area H (stratigraphy: HAF XII-XIII.Iii.Iii), split in 3 fractions.

The high-precision dates have small standard deviations $(1 \sigma)$, ranging between 15 and 25 . The $\delta^{13} \mathrm{C}$ values range from -24.36 to -26.28 . All the charcoal samples seem to have become charred by the same event, the final destruction and conflagration of MBA Jericho. Kenyon (1981) assigned these samples to stratigraphic phases: HAEiv.XII.liib (occupation levels in rooms) and/or HAF.XIIXIII.lii.liii (destruction debris of building phase li). This stratigraphic relation coupled with the homogeneous results of the multiyear charcoal dates, excluding GrN-18538, enabled us to calculate a weighted average, according to the formula given by Mook and Waterbolk (1985). The average ${ }^{14} \mathrm{C}$ date of the 11 charcoal samples has a very small uncertainty: $3370 \pm 6 \mathrm{BP}$. The result probably signifies the last building phase at area $\mathrm{H}$ of MBA Jericho, prior to its destruction. 


\section{Short-Lived Grains}

The six samples of short-lived cereal grains also yielded homogeneous dates (Table 1, Fig. 1), with standard deviations between 14 and 25 . Most of the $\delta^{13} \mathrm{C}$ values are slightly below -23 , with one exception, a sample of fragmented grains that gave a value of -21.86 ( $\mathrm{GrN}-19064)$. The charred grains are either wheat or barley, preserved by carbonization, and investigated botanically by Hopf (1983). The samples are all associated with the same event, the final destruction and conflagration that terminated MBA Jericho, i.e., stratigraphic phase HAF.XII-XIII.lii.liii (Kenyon 1981). The results of GrN-18539, $-18542,-18543,-18544$ are almost identical, again confirming both the contemporary nature of the four samples and the precision of the ${ }^{14} \mathrm{C}$ measurements. The dates of $\mathrm{GrN}$ 19063 and GrN-19064 have a slightly larger spread than the other four, but are still within the 2- $\sigma$ range (Fig.1). Most grains probably date to the last harvest preceding the destruction and conflagration of the tell. It is always possible of course that some grains belonged to a reserve storage, a few years older than the last grain harvest. We calculated the weighted average date of the six grain samples, using the formula by Mook and Waterbolk (1985). The resulting date, $3306 \pm 7 \mathrm{BP}$, is both precise and probably accurate to signify the destruction of MBA Jericho in ${ }^{14} \mathrm{C}$ years (Fig. 3).

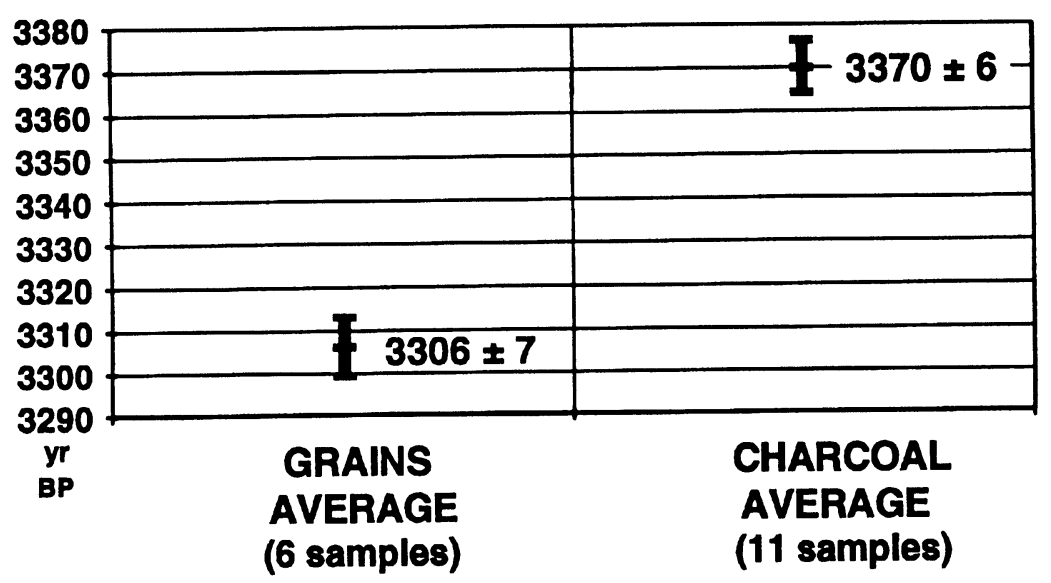

Fig. 3. End of MBA Jericho: Average ${ }^{14} \mathrm{C}$ dated in years BP of short-lived grains and multiyear charcoal

\section{CALIBRATION OF WEIGHTED AVERAGES OF GRAIN AND CHARCOAL DATES: A DISCUSSION}

The bidecadal calibration curves by Stuiver and Pearson (1986) and Pearson and Stuiver (1986), covering the time period from the present to $2500 \mathrm{BC}$, were conventionally endorsed (Mook 1986). Corrections were published in 1993 (Stuiver and Pearson 1993; Pearson and Stuiver 1993), but the original data on Irish wood (Pearson et al. 1986) may still be valid after all, as discussed by Bowman (1994), who reviewed the state of the art in calibration, its use and regional differences (McCormac et al. 1995) between calibration curves. Several groups are currently testing the accuracy of the 1986 and 1993 calibration curves. Therefore, it is a bit premature to make definite statements about the calibration of our very precise ${ }^{14} \mathrm{C}$ BP results.

The weighted averages of the short-lived grains and multiyear charcoal samples have standard deviations which are smaller than those of the calibration curves and the absolute standard of oxalic acid! However, the very precise BP dates coincide with horizontal segments (wiggles) in all calibration curves used. The preliminary calibrated dates are, therefore, considerably less precise than the BP 
date in ${ }^{14} \mathrm{C}$ years. Ideally, a calibration curve ought to be based on single-year dendrochronological data from the Jericho region, particularly for the calibration of the average grain date. Such a wish is utopian for the time being. However, a preliminary indication of the age in historical years may be obtained from current calibration curves and computer calibration programs. Four calibration curves have been used: the bidecadal 1986 and 1993 versions of Pearson and Stuiver, based on Irish oak chronology (Pearson et al. 1986) and German oak chronology (Becker 1993), as well as the decadal 1986 and 1993 versions of Stuiver and Becker, based on German Main-Donau chronology in the required BC time interval. The three computer calibration programs used are CAL20 (previously CAL15) (van der Plicht 1993), CALIB (Stuiver and Reimer 1993) and OxCal (Bronk Ramsey 1995). The latter two programs take account of the standard deviation of the calibration curves. No smoothing of the calibration curve has been used $(S=0)$ in the CAL20 program. The 1986 curves cannot be used in version 3.0.3C of the CALIB program. The calibration results are presented in Figure 4.

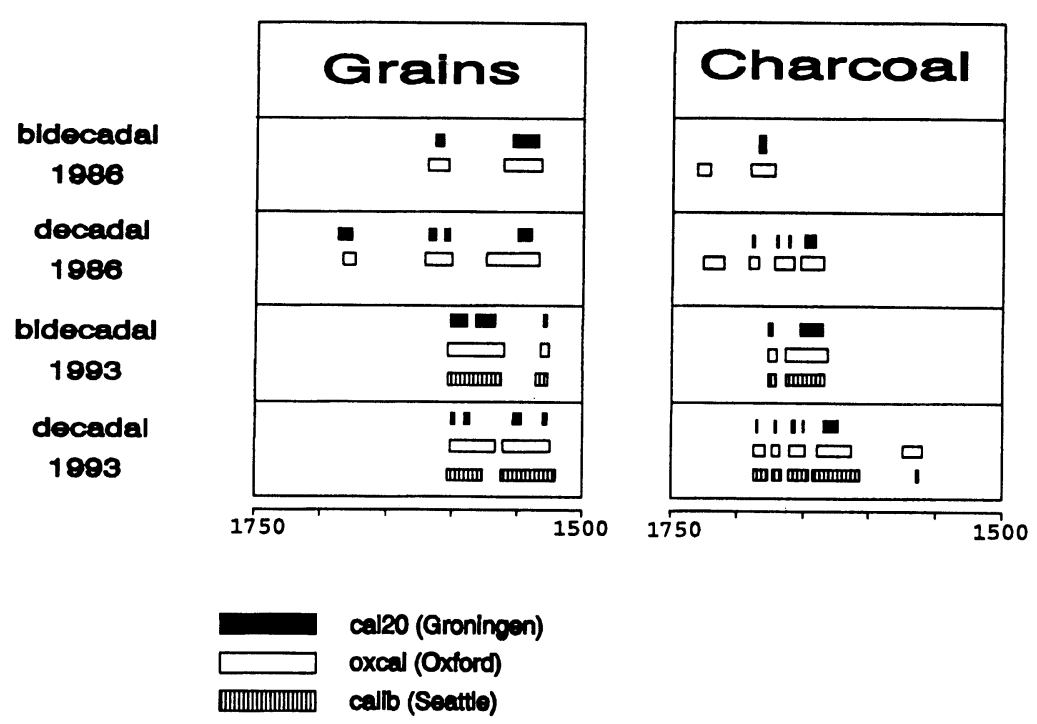

Fig. 4. Preliminary calibration of the weighted average of the grain and charcoal samples, using 4 calibration curves (Pearson and Stuiver 1986, 1993; Stuiver and Becker 1986, 1993) and 3 computer calibration programs (CAL20, van der Plicht 1993; OxCal v2.0, Bronk Ramsey 1995; CALIB v3.0.3C, Stuiver and Reimer 1993).

We have to await further appraisal and reassessment of the above calibration curves before making definite statements about the calibrated results of the Jericho samples. The 1993 version of the bidecadal calibration curve by Pearson and Stuiver gives somewhat younger ages than the $1986 \mathrm{cal}-$ ibration curve. The 1993 version of Stuiver and Becker produces considerably younger dates than their 1986 decadal calibration curve. The 1993 versions of both the bidecadal and decadal calibration curves produce similar dates, but the 1986 versions of these two curves do not give comparable results. Calibrated dates may change with further refinement of both calibration curves and calculation procedures. Therefore, the uncalibrated original BP date must always be mentioned with the calibrated result.

The bidecadal curve of Pearson and Stuiver is preferable for the calibration of the weighted average of the multiyear charcoal samples. This date may reflect the last phase of construction of MBA Jericho in Squares H II, III, VI of the tell, designated by Kenyon (1981) as phase XII.li. Using the 
OxCal computer calibration program, the 1986 curve gives an age range in the latter part of the 18th century BC and in the 17th century BC: $1732-1722 \mathrm{cal} \mathrm{BC}(0.24)^{1}$ and $1691-1673 \mathrm{cal} \mathrm{BC}(0.76)$. If one chooses the 1993 calibration curve of Pearson and Stuiver, the calibrated result gives two ranges within the 17th century BC: $1678-1670 \mathrm{cal} \mathrm{BC}(0.24)$ and $1659-1632 \mathrm{cal} \mathrm{BC}(0.76)$.

Calibration of the weighted average of the grain samples results in ranges in both the 17th and 16th century BC, using the 1986 versions of the two calibration curves. With the 1993 versions, the 17th century option becomes negligible, whereas a date in the 16th century is most likely. The decadal calibration curve is recommended by Stuiver and Becker (1993) for short-lived samples formed during a decade or less. Using this calibration curve to calculate the historical date of the weighted average of the grain samples, with the aid of the OxCal computer calibration program, there is equal probability for the $1 \sigma$ result to be in the range 1601 to $1566 \mathrm{cal} \mathrm{BC}$ as in the range 1561 to $1524 \mathrm{cal}$ $\mathrm{BC}$ for the destruction of MBA Jericho.

The preliminary calibration results provide valuable new and independent chronological information. The ${ }^{14} \mathrm{C}$ dates do not support a low 15 th century $\mathrm{BC}$ chronology for the end of the MBA, as Bimson (1978) proposed. Further, the fortified Bronze Age city at Tell es-Sultan was not destroyed by $c a .1400 \mathrm{BC}$, as Wood (1990) suggested. The archaeological dating of Jericho's destruction by Watzinger (1926) and Kenyon (1957) falls within the preliminary calibrated ranges. However, their archaeological dating is not based on firm chronological evidence but apparently on assumed association with the beginning of the XVIIIth Dynasty in Egypt. This date in the floating Egyptian chronology has gradually shifted from ca. $1580 \mathrm{BC}$ (Breasted 1906), used by Kenyon, to the current low chronology of $1539 \mathrm{BC}$ (Kitchen 1987; Ward 1992). It would be extremely valuable to have new sets of high-precision ${ }^{14} \mathrm{C}$ dates from short-lived material of the Second Intermediate period and the XVIIIth Dynasty in Egypt, to investigate a possible Egyptian connection with the destruction of MBA Jericho. However, the problem and the extent of regional variations between calibration curves need to be addressed. Development of a new high-precision calibration curve for the Eastern Mediterranean region would be ideal, if only the logs could be found.

\section{CONCLUSION}

The two homogeneous data sets of the cereal and charcoal samples indicate that the high-precision BP dates related to the end of MBA Jericho are reliable. The standard deviations of the weighted averages are more precise than the 1- $\sigma$ uncertainty of the calibration curves and the absolute standard of oxalic acid. The charcoal dates are on the average $64{ }^{14} \mathrm{C}$ years older than the cereal dates. Only one charcoal date is an outlier ( $3614 \pm 20 \mathrm{BP}, \mathrm{GrN}-18538)$, for which we have no explanation other than the possibility that the coarse charcoal fragments contained old wood. The weighted average date of the multiyear charcoal ( $3370 \pm 6 \mathrm{BP})$ becomes considerably less precise after calibration, due to wiggles in the calibration curves. Preliminary calibration results, depending on the selection of the calibration curve and the computer calibration method, comprise in broad terms the end of the 18 th century BC and/or the 17 th century BC. The calibrated date of the multiyear charcoal may reflect the time of rebuilding at the Tell (phase XII.li) in Squares H II, III, VI.

The age of the short-lived cereal samples is likely to be within a few years of the destruction date of the last MBA city at Tell es-Sultan. The weighted average of the cereal samples is much more precise in ${ }^{14} \mathrm{C}$ years, $3306 \pm 7 \mathrm{BP}$, than in historical years, due to wiggles in the calibration curves. Calibration with the 1993 decadal curve of Stuiver and Becker, using the OxCal computer calibration

${ }^{1}$ The number in parentheses after the age ranges signifies the relative probability within the $1-\sigma(68.3 \%)$ area. 
program, results in 1- $\sigma$ ranges of equal probability, $1601-1566 \mathrm{cal} \mathrm{BC}$ and $1561-1524 \mathrm{cal} \mathrm{BC}$. This is one of several options for the calibrated destruction date of MBA Jericho, as shown in Figure 4. The uncalibrated original BP date must always be mentioned, because calibrated dates may change with further refinement of both calibration curves and calculation procedures. The preliminary calibration data of the destruction of Tell es-Sultan at the end of the MBA constitute valuable new chronological information, based on detailed and precise ${ }^{14} \mathrm{C}$ measurements. More definite statements about the calibrated dates can be made only after accuracy tests of existing calibration curves and further assessment of regional variability.

\section{ACKNOWLEDGMENTS}

Thanks to Dr. Maria Hopf, Römisch-Germanisches Zentralmuseum, Forschungsinstitut für Vor- und Frühgeschichte, Mainz, and Mr. Peter Parr, University of London, Institute of Archaeology, for kindly making available material excavated in the 1950s under the direction of the late Dame Kathleen Kenyon. We very much appreciate the expertise and precise methodology of Mr. H. J. Streurman, University of Groningen, Centre for Isotope Research, in dating the samples.

\section{REFERENCES}

Bimson, J. J. 1978 Redating the exodus and conquest. Journal for the Study of the Old Testament, Supplement Series 5.

Bowman, S. G. E. 1994 Using radiocarbon: An update. Antiquity 68: 838-843.

Bowman, S. G. E., Ambers, J. C. and Leese, M. N. 1990 Re-evaluation of British Museum radiocarbon dates issued between 1980 and 1984. Radiocarbon 32(1): 59-79.

Breasted, J. H. 1906 Ancient Records of Egypt, Volume 1. London, Histories \& Mysteries of Man Ltd. (Reprinted 1988, Irvine, California, M. S. Sanders, Publisher.)

Bronk Ramsey, C. 1995 Radiocarbon calibration and analysis of stratigraphy and the OxCal program. This issue.

Bruins, H. J. 1994 Comparative chronology of climate and human history in the southern Levant from the Late Chalcolithic to the Early Arab Period. In BarYosef, O. and Kra, R. S., eds. Late Quaternary Chronology and Paleoclimates of the Eastern Mediterranean. Tucson, Arizona, Radiocarbon: 301-314.

Bruins, H. J. and W. G. Mook 1989 The need for a calibrated radiocarbon chronology of Near Eastern archaeology. In Long, A., Kra, R. S. and Srdox, D., Proceedings of the 13 th International ${ }^{14} \mathrm{C}$ Conference. Radiocarbon 31(3): 1019-1029.

Burleigh, R. 1981 Radiocarbon dates. In Kenyon, K. M., edited by Holland, T. A., Excavations at Jericho, Volume 3. The Architecture and Stratigraphy of the Tell, Appendix C, London, The British School of Archaeology in Jerusalem: 501-504.

1983 Additional radiocarbon dates for Jericho. In Kenyon, K. M. and Holland, T. A. Excavations at Jericho, Volume 5. The Pottery Phases of the Tell and Other Finds. Appendix D, London, The British
School of Archaeology in Jerusalem: 760-765.

Dever, W. G. 1992 The chronology of Syria-Palestine in the second millennium B.C.E.: A review of current issues. Bulletin of the American Schools for Oriental Research (BASOR) 288: 1-25.

Garstang, J. and Garstang, J. B. E. 1948 The Story of Jericho. London: Marshall, Morgan and Scott (revised edition).

Hopf, M. 1983 Jericho plant remains. In Kenyon, K. M. and Holland, T. A. Excavations at Jericho, Volume 5. The Pottery Phases of the Tell and Other Finds. Appendix B, London, The British School of Archaeology in Jerusalem: 576-621, Plates 25-31.

Kenyon, K. M. 1957 Digging Up Jericho. London, Ernst Benn Ltd., 272p. 1960 Archaeology in the Holy Land. London, Ernest Benn Ltd., 326p.

1981 Excavations at Jericho, Volume 3. The Architecture and Stratigraphy of the Tell. London, The British School of Archaeology in Jerusalem.

Kitchen, K. A. 1987 The basics of Egyptian chronology in relation to the Bronze Age. In Åström, P., ed., High, Middle or Low. Acts of an International Colloquium on Absolute Chronology. Gothenburg, Paul Åströms Förlag: 37-55.

McCormac, F. G., Baillie, M. G. L., Pilcher, J. R., Jirikovic, J. and Kalin, R. M. 1996 Indications of location-dependent differences in the ${ }^{14} \mathrm{C}$ content of wood and a possible solar connection. Radiocarbon, in press.

Mook, W. G. and Waterbolk, H. T. 1985 Handbook for Archaeologists. No. 3. Radiocarbon Dating. Strasbourg: European Science Foundation.

Pearson, G. W. and Stuiver, M. 1986 High-precision calibration of the radiocarbon time scale, $500-2500 \mathrm{BC}$. In Stuiver, M. and Kra, R. S., eds., Proceedings of the 
12th International ${ }^{14} \mathrm{C}$ Conference. Radiocarbon 28 (2B): 839-862.

Pearson, G. W. and Stuiver, M. 1993 High-precision bidecadal calibration of the radiocarbon time scale, 500-2500 BC. In Stuiver, M., Long, A. and Kra, R. S., Calibration 1993. Radiocarbon 35(1): 25-34.

Sellin, E. and Watzinger, C. 1913 Jericho: Die Ergebnisse der Ausgrabungen (Jericho). Leipzig, J. C. Hinrichs.

Stuiver, M. and Becker, B. 1986 High-precision decadal calibration of the radiocarbon time scale, AD 19502500 BC. In Stuiver, M. and Kra, R. S., eds., Proceedings of the 12 th International ${ }^{14} \mathrm{C}$ Conference. Radiocarbon 28(2B): 863-910.

1986 High-precision decadal calibration of the radiocarbon time scale, AD 1950-2500 BC. In Stuiver, M., Long, A. and Kra, R. S. eds., Calibration 1993. Radiocarbon 35(1): 35-65.

Stuiver, M. and Reimer, P. J. 1993 Extended ${ }^{14} \mathrm{C}$ data base and revised CALIB $3.0{ }^{14} \mathrm{C}$ age calibration program. In Stuiver, M., Long, A. and Kra, R. S., eds., Calibration 1993. Radiocarbon 35(1): 215-230.

Tite, M. S., Bowman, S. G. E., Ambers, J. C. and Matthews, K. J. 1987 Preliminary statement on an error in British Museum radiocarbon dates (BM-1700 to BM-
2315). Antiquity 61: 168.

van der Plicht, J. 1993 The Groningen radiocarbon calibration program. In Stuiver, M., Long, A., and Kra, R. S., eds., Calibration 1993. Radiocarbon 35(1): 231237.

Ward, W. A. 1992 The present status of Egyptian chronology. Bulletin of the American Schools for Oriental Research (BASOR) 288: 53-66.

Warren, C. 1883 Report. In Conder, C.R. and Kitchener, H. H. The Survey of Western Palestine, Vol. 3. London, Committee of the Palestine Exploration Fund: 224 226.

Watzinger, C. 1926 Zur Chronologie der Schichten von Jericho. Zeitschrift der Deutschen Morgenländischen Gessellschaft 80: 131-136.

Weinstein, J. 1981 The Egyptian empire in Palestine: A reassessment. Bulletin of the American Schools for Oriental Research (BASOR) 241: 1-28.

1991 Egypt and the Middle Bronze IIC/Late Bronze IA transition in Palestine. Levant 23: 105-115.

Western, A. C. 1971 The ecological interpretation of ancient charcoals from Jericho. Levant 3: 31-40.

Wood, B. G. 1990 Dating Jericho's destruction: Bienkowski is wrong on all counts. Biblical Archaeology Review 16: 45-69. 